\title{
Strategic Decision Making Based on Information Systems for Improving the Competitiveness of Small and Medium Enterprises in the Trade Sector of the City Tourism and Trade
}

\author{
Arasy Alimudin ${ }^{1}$, Soebandi ${ }^{1}$, Achmad Zaki Fallani ${ }^{2}$, Bustomi Arifin ${ }^{3}$ \\ ${ }^{1}$ Department of Management, Narotama University of Surabaya, Indonesia \\ Email: arasybest@gmail.com \\ ${ }^{2}$ Department of Informatics Engineering, Narotama University of Surabaya, Indonesia \\ ${ }^{3}$ Department of Education, Narotama University of Surabaya, Indonesia
}

\begin{abstract}
The main shortcomings of micro, small and medium enterprises in Indonesia are located into its traditional management system coupled with lack of utilization of information and technology. Economic and trading growth in Surabaya, Malang and Batu are higher compared to national economic and trading growth. Information and technology are essential factor in improving strategic competitiveness of grocery since it can be used to seek information about customer to gain their trust and satisfaction. The present study shows that strategic competitiveness of grocery in Surabaya and Malang is based on service and product quality. Meanwhile, strategic competitiveness in Batu is based on pricing of the product. Utilization of information and technology in making strategic competitiveness decision obtain the same result as conventional statistics analysis.
\end{abstract}

Keywords: Small and Micro Enterprises,Competitiveness,Strategic,Business Decision,Information System

\section{INTRODUCTION}

Precise decision making for developing business in information and technology era nowadays is highly demanded. Delay in making decision stimulates loss of business opportunity coupled with hamper the growth of business to become stagnant or even failed. Economic growth of Indonesia in 2015 was around 4, 79\% in which it decreased compared to 2014 which around 5, 02\%. Economic growth of East Java province in 2015 was around 5, 44\% or slowed down around 0, 42 point compared to 2014 which was around 5, 86\%. Commerce industry in Indonesia within 5 years is experiencing steady growth around 13,24\%. Steady growth of commerce industry for East Java province in 2015 was exceeding the national growth which was around 17, 29\%. Surabaya as the capital of East Java holds around 18,56\% within commerce industry mainly micro enterprises since it has around 1.538 micro enterprises that hold micro trading business permits and 4.062 small enterprises that hold small trading business permits [3] .Economic growth of Malang in 2015 was around $5,61 \%$. It is influenced by strategic location of Malang which is located nearby Batu as one of the national tourism destination in East Java. The economic growth of Malang can be seen from its Gross Domestic Regional Product (restaurant, hotel and commerce) was around 37, 67\% in 2015. Batu is tourism city which possesses commerce growth around $6,44 \%$ from 116 enterprises that hold micro trading business permits and around 23 enterprises that hold small trading business permits [3]. Batu city gave 41 tourism objects which are 14 natural tourism objects, 19 artificial tourism objects, 10 cultural objects which dispersed in 3 districts. The total number of tourists who came to Batu city around 2,089,022 visitors therefore the existence of groceries needs to be located nearby tourism objects in Batu to achieve customer satisfaction [10]. Information concerning product discount and special offer are needed by customer in order to gain customer trust and satisfaction [15]. This condition demands technology and information to maintain and improve competitiveness strategy since technology and information are able to provide quick access for customer in getting information about the product. Based on interview with the vice minister of commerce Mr. Bayu Krisnamurthi in August 2014, there are around 75.000 small and medium enterprises who are using internet in conducting their business (detik, 2014). Therefore it can be assumed that small and medium enterprises nowadays are utilizing information and technology as the marketing media in improving their business. 
technology [7],[8]. Moreover, user behavior can be used to see user willingness coupled with adaptability to adopt information and technology in order to enhance competitiveness of the company. Commonly, managerial system of grocery possesses traditional behavior in conducting business therefore adoption of information and technology for grocery can be seen as solution to make and plan strategic decision. In order to attract grocery owner in using information and technology, simple design computer application will be suitable to be used by grocery in developing their business. Therefore, in order to make quick decision, we need computer to accelerate drafting proses in making business strategic plan.

Table 3. Analysis of Internal and External Environmental variable grocery store in Surabaya, Batu and Malang (mean)

\begin{tabular}{|c|c|c|c|c|c|c|}
\hline \multirow{2}{*}{ City } & \multicolumn{3}{|c|}{ Internal } & \multicolumn{3}{c|}{ External } \\
\cline { 2 - 7 } & Product Price & $\begin{array}{c}\text { Consumer } \\
\text { number }\end{array}$ & $\begin{array}{c}\text { Production } \\
\text { Cost/bulan }\end{array}$ & $\begin{array}{c}\text { Competitor } \\
\text { number }\end{array}$ & $\begin{array}{c}\text { Competit } \\
\text { or Price }\end{array}$ & $\begin{array}{c}\text { Distance } \\
\text { location of } \\
\text { competitor }\end{array}$ \\
\hline Surabaya & Market Price & 55 & 6.000 .000 & 8 & $\begin{array}{c}\text { Market } \\
\text { Price }\end{array}$ & 157 \\
\hline Batu & $\begin{array}{c}\text { higher Market } \\
\text { Price }\end{array}$ & 34 & 4.220 .000 & 3 & higher & 227 meter \\
\hline Malang & $\begin{array}{c}\text { higher Market } \\
\text { Price }\end{array}$ & 38 & 5.241 .000 & 7 & higher & 275 meter \\
\hline
\end{tabular}

Based on the analysis crosstab that the selling price and customers have shown a significant relationship with a significance value of $0.012>0.05$, meaning at the level of $95 \%$ selling price have a real relationship with the number of subscribers. Multivariate analysis can be concluded that on the whole the independent variables suspected to affect the price competitiveness of the grocery store, there is one subvariable (operating costs) are most influential on the price competitiveness of the grocery store with $\mathrm{p}$ value $0,000<0,05$. a grocery store in Surabaya actually have lower operating costs, but because of their efforts the average loan to third party, the burden of interest costs were high enough to make their operating costs equal as its competitors.

\section{DISCUSSION}

Strategic location of grocery store can be regarded as attractive factor in developing commerce business mainly for start-up and home-based business. Therefore, grocery store located nearby tourism area should be able to increase competitiveness advantage for sustaining and improving business. Utilization of information and technology are new gateway to create cost efficiency. Dimitrios Buhalis stated that information and technology are able to transform the strategic position of organizations by altering their efficiency, differentiation, operational cost and response time. In particular, information and technology stimulate radical changes in operation and distribution of the tourism industry.

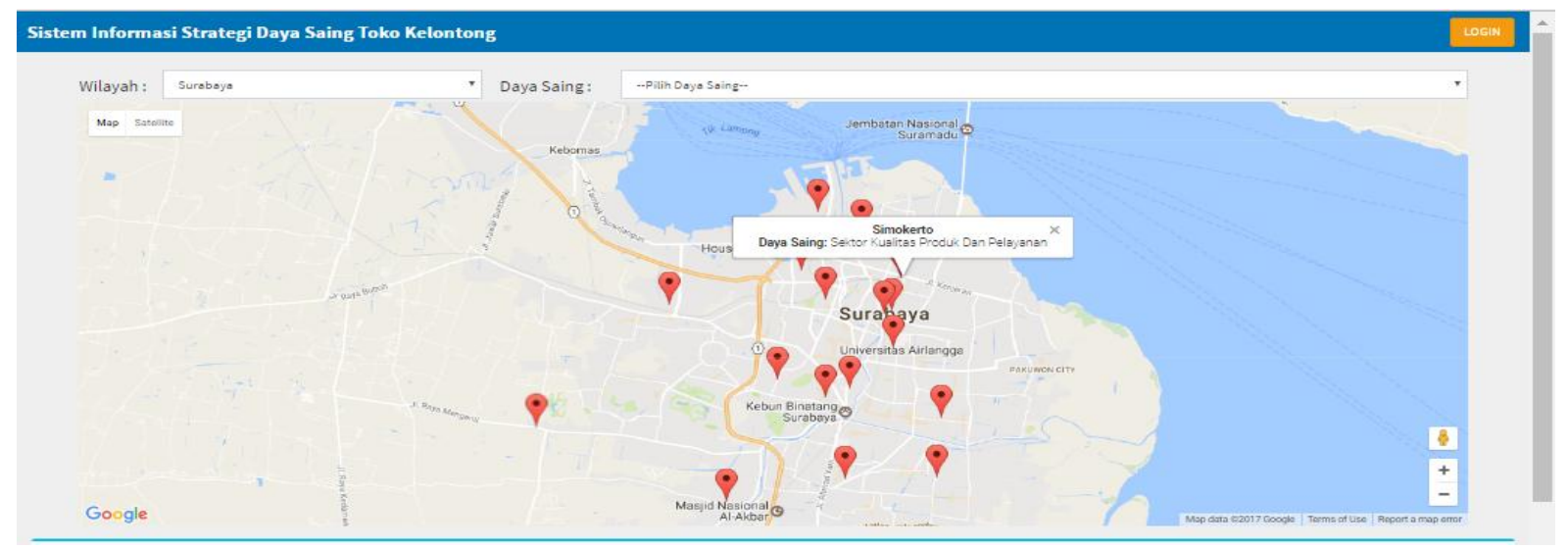

Figure 1. Utilization of information and technology to depict grocery store Competitiveness in Surabaya city source: Information System of Groceries Strategic Competitiveness in Surabaya available at http://118.97.247.164/fuzzy/ 
A grocery store in Surabaya should be able to keep its customers not to move to a competitor by creating a familial relationship with its customers. The use of IT will be able to manage and keep customers trust.

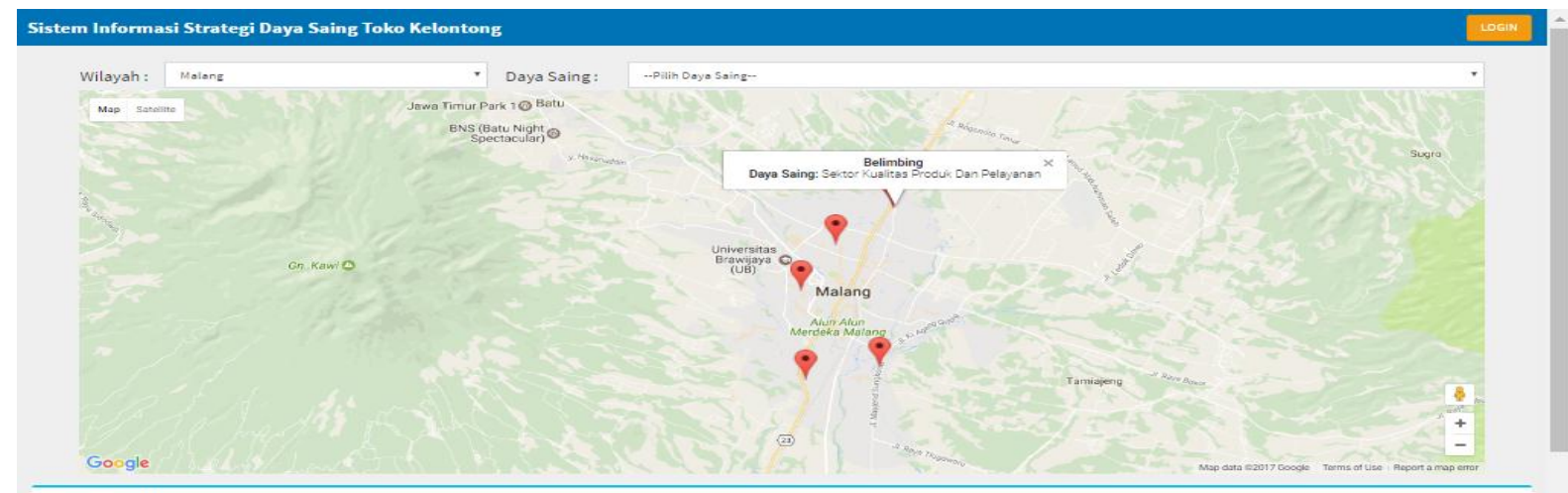

Figur.2 Utilization of information and technology to depict grocery store Competitiveness in Malang city: source: Information System of Groceries Strategic Competitiveness in Malang available at http://118.97.247.164/fuzzy/

Strategic location of grocery stores in Malang should be able to keep its customers not to move to competitors therefore grocery stores need to manage stock and variation of products according to customers needed.

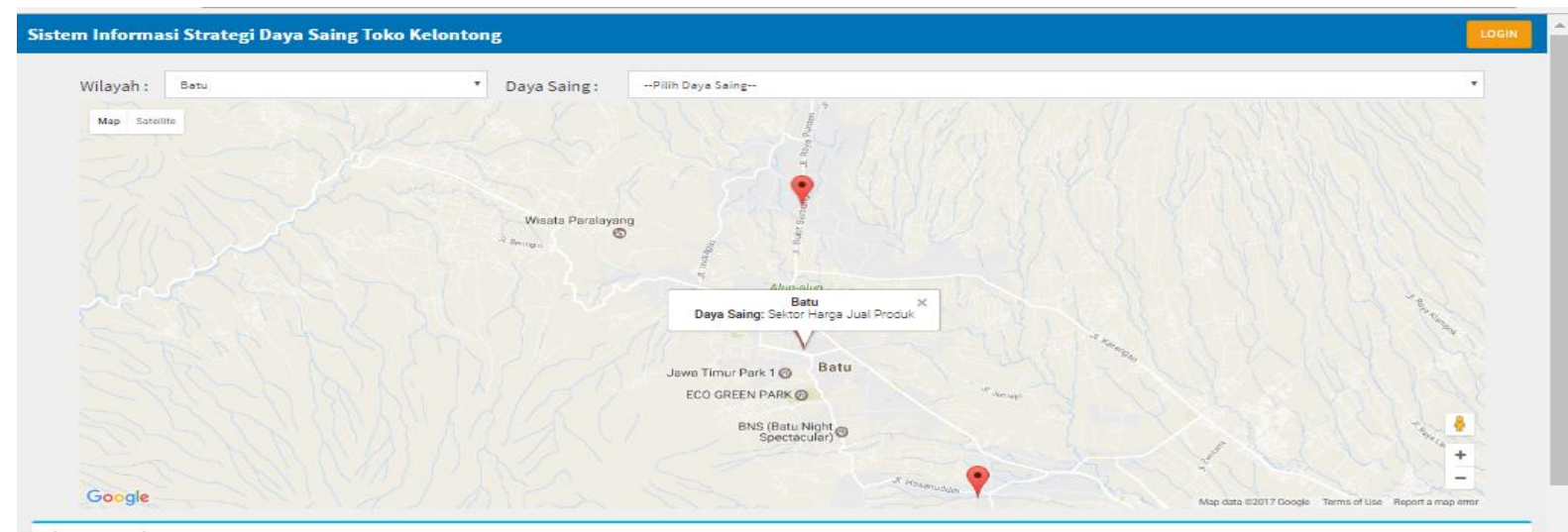

Figur. 3 Utilization of information and technology to depict grocery store Competitiveness in Batu city Source: Information System of Groceries Strategic Competitiveness in Batu available at http://118.97.247.164/fuzzy/

Grocery stores in Batu are still relatively moderate since it is located nearby the area of tourism therefore those stores must be able to maintain stability of price competitiveness by reducing production cost by not selling products that are not popular within customers. The distance of grocery stores that are bit far from the tourism center and the presence of mini market as competitor urge grocery stores to be more creative in creating excellence service and price. Utilization of information and technology greatly assist the grocery stores in reducing marketing costs and increasing competitiveness price.

\section{CONCLUSION}

Utilization of information and technology are effective and efficient in making proper decisions to improve the competitiveness of grocery stores in Surabaya (commerce and industrial city), Malang and Batu (tourism city). The development of information and technology systems that support the competitiveness of grocery stores are necessary to maintain and improve business growth of grocery 
store in industrial and tourism areas. The main shortcomings for grocery stores in utilizing information and technology to make strategic decision related to the competitiveness strategy toward competitors are the high production cost of information and technology coupled with maintenance of data server.

\section{REFERENCES}

[1] Alimudin, A. (2013). Pengaruh Orientasi Wirausaha Terhadap Keunggulan Bersaing Berkelanjutan Dan Kinerja Pemasaran Usaha Kecil Sektor Perdagangan (Consumer Goods) Di Kota Surabaya. Sustainable Competitive Advantage (SCA), 3(1).

[2] Bharadwaj, S. G., Varadarajan, P. R., \& Fahy, J. (1993). Competitive Advantage in Service Industries: A Conceptual Model. Journal of Marketing, 57(4), 83-99.

[3] BPS Provinsi Jawa Timur/Statistics of Jawa Timur Province. (2016). Jawa Timur Province in Figures 2016.

[4] Bracker, J. S., Keats, B. W., \& Pearson, J. N. (1988). Planning And Financial Performance Among Small Firms In A G. Strategic Management Journal, 9(6), 591. Retrieved from http://fetch. mhsl.uab.edu/login?url=http://search.proquest.com/docview/224989302?accountid= 8240\%5Cnhttp://ak7rt6cb3z.search.serialssolutions.com/uab? \&spage=591\&atitle=Planning + An $\mathrm{d}+$ Financial+Performance+Among+Small+Firms+In+A+G\&sid=ProQ:\&title=Strategic + Ma

[5] Covin, J. G., \& Covin, T. J. (1990). Competitive agressiveness, environmental context, and small firm performance. Entrepreneurship: Theory \& Practice, 14(4), 35-50.

[6] Cravens, D., \& Piercy, N. F. (2008). Strategic marketing. Journal of the American College of Radiology JACR, 3(4), 287. Retrieved from http://webcat.warwick.ac.uk/record=b2229978

[7] Davis, F. D. (1989). Information Technology Introduction. Management Information Systems Quarterly, 13(3), 319-340. https://doi.org/10.1016/j.jcrysgro.2008.09.185

[8] Ferguson, C. (1997). The effects of microcomputers on the work of professional accountants. Accounting and Finance, 37(1), 41-67. https://doi.org/10.1111/j.1467-629X.1997.tb00313.x

[9] Fitzsimmons, J. A., \& Fitzsimmons, M. J. (1994). Service management for competitive advantage (13th ed.). New York: McGraw-Hill.

[10] Fornell, C. (1992). A National Customer Satisfaction Barome- ter: The Swedish Experience. Journal of Marketing, 56(1), 6-21.

[11] Grant, R. M. (1991). The Resource-Based Theory of Competitive Advantage: Implications for Strategy Formulation. California Management Review, 33(3), 114-135. https://doi.org/10.2307/ 41166664

[12] Hooley, G., Broderick, A., \& Möller, K. (1998). Competitive positioning and the resource based view of the firm. Journal of Strategic Marketing, 6(2), 97-116.

[13] Hosmer, D. W., \& Lemeshow, S. (2000). Applied logistic regression. Wiley Series in Probability and Statistics (Vol. 2nd). https://doi.org/10.1198/tech.2002.s650

[14] Iffah, M., Sutikno, F. R., \& Sari, N. (2011). Pengaruh Toko Modern terhadap Toko Usaha Kecil Skala Lingkungan (Studi Kasus : Minimarket Kecamatan Blimbing, Kota Malang). Jurnal Tata Kota Dan Daerah, 3, 55-64.

[15] Kandampully, J., Suhartanto, D., \& Kandampully, J. (2000). International Journal of Contemporary Hospitality Management customer satisfaction and image Customer loyalty in the hotel industry: the role of customer satisfaction and image. International Journal of Contemporary Hospitality Management International Journal of Contemporary Hospitality Management Iss Journal of Consumer Marketing, 12(5), 346-351. Retrieved from http://dx.doi.org/10.1108/ 09596110010342559

[16] Kotler, P. (2000). Marketing Management, Millenium Edition. Marketing Management, 23(6), 188-193. https://doi.org/10.1016/0024-6301(90)90145-T

[17] Kotler, P., \& Armstrong, G. (2004). Principles of Marketing. World Wide Web Internet And Web Information Systems. https://doi.org/10.2307/1250103

[18] Krajewski, L., Ritzman, L., \& MK, M. (2007). Operations Management - Processes and Value Chain. International Journal of Production Economics. https://doi.org/10.1016/j.ijpe.2008. 07.023

[19] Mahoney, J. T., \& Pandian, J. R. (1992). 1992 The resource-based view within the conversation of strategic management. Strategic Management Journal. https://doi.org/10.2307/2486455 
[20] Mata, F. J., Fuerst, W. L., \& Barney, J. B. (1995). Information Technology and sustained competitive advantage: A resource based analysis. MIS Quarterly, 19(4), 487-505.

[21] Minister of Finance. (2003). Decree of the Minister of Finance No. 40/KMK.06/2003, Retrieved from http://www.jdih.kemenkeu.go.id/fulltext/2000/544 KMK.04 2000Kep.htm

[22] Pearce, J. A., Robbins, D. K., \& Robinson, R. B. (1987). The impact of grand strategy and planning formality on financial performance. Strategic Management Journal, 8(2), 125-134. https://doi.org/10.1002/smj.4250080204

[23] Porter, M. E. (1985). Competitive Advantage. Management Information Systems (Vol. 19). https://doi.org/10.1182/blood-2005-11-4354

[24] Robbins, S. P., \& Coulter, M. (2005). Manajemen. In Management.

[25] Sashi, C. M., \& Stern, L. W. (1995). Product differentiation and market performance in producer goods industries. Journal of Business Research, 33(2), 115-127. https://doi.org/10.1016/0148-2963(94)00062-J

[26] Scupola, A. (2003). The Adoption of Internet Commerce by SMEs in the South of Italy: An Environmental, Technological and Organizational Perspective. Journal of Global Information Technology Management, 6(1), 52-71. https://doi.org/10.1080/1097198X.2003.10856343

[27] Scupola, A. (2009). SMEs' e-commerce adoption: perspectives from Denmark and Australia. Journal of Enterprise Information Management, 22(1/2), 152-166. https://doi.org/10.1108/ 17410390910932803

[28] Sugiyono. (2010). Metode Penelitian Bisnis. Pendekatan Kuantitatif, kualitatif dan R \& D. Bandung: Alfabeta, 15(2010), 90. https://doi.org/10.1016/S0969-4765(04)00066-9

[29] Sulaiman, W. (2003). Statistik Non Parametrik: Contoh Kasus dan Pemecahannya dengan SPSS. (1st ed.). Yogyakarta: Andi.

[30] Thompson, R. L., Higgins, C. A., \& Howell, J. M. (1991). Personal Computing: Toward a Conceptual Model of Utilization. MIS Quarterly, 15(1), 125. https://doi.org/10.2307/249443

[31] Todd, Chin, W. W., \& A, P. (2010). Note of Caution On the Use, Usefulness, and Ease of Use of Structural Equation Modeling in MIS Research : A Note of Caution, 19(2), 237-246.

[32] Turban, E., Aronson, J. E., \& Liang, T.-P. (2007). Decision Support Systems and Intelligent Systems. Decision Support Systems and Intelligent Systems, 7, 867. Retrieved from http://www.amazon. co.uk/dp/0131230131

[33] Ward, P. T., Leong, G. K., \& Boyer, K. K. (1994). Manufacturing Proactiveness and Performance. Decision Sciences, 25(3), 337-358. https://doi.org/10.1111/j.1540-5915.1994. tb00808.x

[34] Wijayanti, Pardiana, \& Wiratno. (2011). Analisis Pengaruh Perubahan Keuntungan Usaha Warung tradisional Dengan Munculnya Minimarket (Studi Kasus Di Kecamatan Pedurungan Kota Semarang), 71-85. 